Vol. 17 No. 34 Juli - Desember 2018

\title{
STRATEGI PROMOSI WISATA RELIGI MAKAM \\ SYEKH SURGI MUFTI
}

\section{Devi Noviyanti}

UIN Antasari Banjarmasin

\begin{abstract}
Indonesia is a pluralistic country. This plurality produces Indonesia rich in various aspects, such as ethnicity, language, culture and religion so that it supports the fields for sustainable development. South Kalimantan, which is one of the provinces in Indonesia, has a great potential to be developed into an attractive business opportunity because of the number of tourist objects that can be visited by tourists, both domestic and foreign. South Kalimantan offers typical local cultural characters such as the typical Banjar traditional house, Agung Amuntai Temple, Floating Market, typical Banjar fabric craftsmen village, Sasirangan and others. In addition to offering natural and cultural attractions. South Kalimantan is also famous for its religious tourism where one is expected to be the tomb of the famous Ulama which is visited by pilgrims, namely the dome of Surgi Mufti KH. Jamaluddin who also came from a great ulama from South Kalimantan, Sheikh Muhammad Arsyad Al-Banjari. The Surgi Mufti Dome is also one of the pilgrimage attractions designated as cultural heritage sites approved by the Republic of Indonesia Law Number 11 of 2010. The Dome of the Surgi Mufti is located on Jalan Mesjid Jami, Surgi Mufti Village, North Banjarmasin District, Banjarmasin City. In order to develop tourism objects in the South Kalimantan region, one of them is the Tomb of Sheikh Surgi Mufti, so tourism promotion or communication efforts are needed as a strategy that can provide information on tourist destinations in detail and clearly.
\end{abstract}

Keywords: Promotion Strategy; Religious Tourism 


\section{Pendahuluan}

Indonesia merupakan negara yang majemuk. Kemajemukan ini mengakibatkan Indonesia kaya dari berbagai aspek, seperti suku, bahasa daerah, budaya dan agama. Kemajemukan ini memberikan dampak yang positif bagi Indonesia khususnya dari sektor pariwisata, salah satunya melalui sumbangan devisa. Oleh karena itu, sekarang ini perhatian pemerintah tidak bisa lepas dari bidang pariwisata ini. Potensi-potensi di bidang pariwisata jika dapat dioptimalkan tentunya akan berdampak pada meningkatnya perekonomian pada suatu daerah. Dengan harapan bahwa sektor pariwisata dapat menjadi komoditas unggulan yang dapat memacu pertumbuhan ekonomi daerah, dan membantu memberdayakan perekonomian masyarakat serta dapat menambah lapangan pekerjaan bagi masyarakatnya melalui kesempatan berusaha yang seluas-luasnya.

Pada saat ini, bidang pariwisata dirasakan mengalami perkembangan yang luar biasa, meskipun sebenarnya perkembangan ini tidak melalui jalan mulus tanpa hambatan. Isu terorisme, seperti pengeboman yang terjadi di Bali pada 12 Oktober 2012 mengakibatkan timbulnya anggapan bahwa negara Indonesia tidak aman dikunjungi. Hal ini berdampak pada turunnya wisatawan yang berkunjung ke Indonesia. Namun pada tahun 2008, pemerintah berusaha membangkitkan kembali pariwisata Indonesia melalui Visit Indonesia Year 2008 dengan mengambil tema Kebangkitan Nasional. Pada tahun inilah slogan "Unity in Diversity" (Bhinneka Tunggal Ika) mulai digaungkan. Meskipun tema yang diangkat belum menggambarkan dengan jelas apa produk pariwisata Indonesia yang hendak dijual.

Perkembangan di bidang pariwisata ini sebenarnya tidak lepas dari Instruksi Presiden RI No. 9 Tahun 1969 tentang Pedoman Pembinaan Pengembangan Kepariwisataan Nasional. Usaha-usaha 
yang dilakukan sesuai dengan pasal 4 Inpres No. 9 Tahun 1969 adalah sebagai berikut :73

1. Memelihara/membina keindahan dan kekayaan alam serta kebudayaan masyarakat Indonesia sebagai daya tarik kepariwisataan;

2. Menyediakan/membina fasilitas-fasilitas transportasi, akomodasi, entertainment dan pelayanan pariwisata lainnya yang diperlukan, termasuk pendidikan kader;

3. Menyelenggarakan promosi kepariwisataan secara aktif dan efektif di dalam maupun di luar negeri

4. Mengusahakan kelancaran formalitas-formalitas perjalanan dan lalu-lintas para wisatawan dan demikian menghilangkan unsurunsur yang menghambatnya;

5. Mengarahkan kebijaksanaan dan kegiatan perhubungan, khususnya perhubungan udara, sebagai sarana utama guna memperbesar jumlah dan melancarkan arus wisatawan.

Pariwisata modern adalah konsep pariwisata yang mendefinisikan dirinya sebagai produk bisnis modern. Semua produk pariwisata didesain sebagai produk bisnis, mulai dari destinasi, ekonomi kreatif, transportasi, perhotelan, venue rekreasi, atraksi seni dalam paket-paket wisata yang menarik, mengagumkan, menantang dan mengesankan. ${ }^{74}$ Sektor pariwisata sesungguhnya merupakan suatu industri yang apabila digarap secara maksimal dapat memberikan keuntungan yang luar biasa. Sektor pariwisata sejatinya dapat meningkatkan rasa kebanggaan masyarakat terhadap budaya yang dimiliki oleh masing-masing daerahnya, mampu mendorong

${ }^{73}$ https://hotel-management.binus.ac.id/2015/11/18/perkembangan-pariwisata-indonesia/

${ }^{74}$ Bungin, Burhan. 2015. Komunikasi Pariwisata (Tourism Communication) : Pemasaran dan Brand Destinasi. 
pembangunan di daerah tersebut dan berpotensi mengurangi kemiskinan dan pengangguran melalui penciptaaan lapangan pekerjaan dan kesempatan usaha. Ada berbagai jenis kepariwisataan yang dapat dikembangkan di berbagai daerah di Indonesia diantaranya wisata alam, wisata kuliner, wisata budaya, wisata agama/wisata religi dan masih banyak lagi. Dimana salah satu yang dapat diandalkan karena menyimpan potensi yang besar adalah wisata religi. Wisata religi merupakan salah satu alternatif bidang pariwisata yang kental dengan unsur-unsur nilai rohani dan budaya yang ada pada suatu masyarakat. Banyak sekali tempat-tempat yang tentunya memiliki nilai sejarah, budaya dan rohani bagi umat beragama di Indonesia. Selain itu, Indonesia yang memiliki jumlah penduduk umat beragama yang besar tentu menyimpan potensi bagi perkembangan wisata religi di Indonesia.

Wisata religi sendiri dapat diartikan sebagai sektor wisata yang bertujuan untuk memenuhi segala kebutuhan manusia dari sudut pandang spiritualnya dan sebagai sarana untuk memperkuat keimanan dan ketakwaan serta berkunjung ke tempat, bangunan, makam yang memiliki nilai religius dan bersejarah. Beberapa contoh nyata wisata religi adalah umroh dan haji ke Mekkah, mengunjungi makam para ulama terkenal, dan ziarah wali songo dan lain sebagainya. Bahkan bisa dikatakan hampir setiap daerah di Indonesia memiliki beberapa tempat/objek wisata religi. Wisata religi juga tergolong menarik karena tidak pernah sepi peminatnya dikarenakan budaya yang mengakar pada masyarakatnya.

Banjarmasin yang mempunyai julukan Kota Seribu sungai dan merupakan ibukota provinsi Kalimantan Selatan diketahui memiliki banyak sekali tempat yang bisa dijadikan sebagai destinasi wisata. Sektor pariwisata di Kalimantan Selatan menyimpan potensi yang 
besar untuk dikembangkan menjadi sebuah peluang usaha menarik karena banyaknya objek-objek wisata yang dapat dikunjungi oleh wisatawan, baik dari dalam negeri maupun dari luar negeri. Kalimantan Selatan juga mempunyai beberapa jenis objek wisata alam seperti gunung, hutan, laut, pulau, pantai dan sungai. Selain itu, sektor pariwisata yang ada di Kalimantan Selatan juga menawarkan karakter lokal budayanya yang khas seperti Rumah adat khas Banjar, Candi Agung Amuntai, Pasar Terapung, kampung pengrajin kain khas banjar Sasirangan dan lain-lain. Di samping menawarkan objek wisata alam dan budaya, Kalimantan Selatan juga terkenal dengan wisata religinya dimana salah satu di antaranya adalah makam Ulama terkenal yang ramai dikunjungi para peziarah yaitu kubah Surgi Mufti $\mathrm{KH}$. Jamaluddin yang juga merupakan keturunan ulama besar asal Kalimantan Selatan, Syekh Muhammad Arsyad Al-Banjari. Kubah Surgi Mufti juga menjadi salah satu objek wisata ziarah yang ditetapkan sebagai situs cagar budaya yang dilindungi oleh UndangUndang Republik Indonesia Nomor 11 Tahun 2010. Kubah Surgi Mufti berlokasi di kawasan Jalan Mesjid Jami, Kelurahan Surgi Mufti, Kecamatan Banjarmasin Utara, Kota Banjarmasin.

Secara umum dalam rangka pengembangan objek wisata di kawasan Banjarmasin diperlukan keterlibatan berbagai pihak, baik dari kalangan pemerintah, pengusaha, masyarakat dan juga para pemerhati budaya di Kalimantan Selatan. Diperlukan upaya promosi atau komunikasi pariwisata yang mampu menyajikan suatu informasi mengenai suatu destinasi wisata secara detail dan jelas. Informasi mengenai pariwisata yang dapat disajikan harus mampu menggambarkan keadaan yang sesungguhnya dan cukup menarik untuk meningkatkan minat masyarakat sehingga mereka tertarik untuk berkunjung. Peran promosi sangat penting bagi sektor 
pariwisata karena melalui upaya promosi maka objek wisata akan semakin terkenal sehingga wisatawan akan semakin tertarik untuk berkunjung apalagi jika promosi yang dilakukan dapat dipadukan dengan teknologi informasi yang ada maka informasi yang tersaji dapat lebih cepat dan aktual.

Berdasarkan pada hal tersebut di atas, maka perlu dilakukan upaya pengembangan promosi wisata religi di Kalimantan Selatan, salah satunya kubah Surgi Mufti KH. Jamaluddin. Hal ini juga sekaligus menggali potensi yang dimiliki oleh daerah agar dapat menjadi daya tarik bagi wisatawan untuk berkunjung sehingga mampu menjadi magnet perekonomian yang akan meningkatkan pertumbuhan ekonomi. Selain itu, diharapkan pula dapat membuka lapangan pekerjaan baru bagi masyarakatnya melalui kesempatan berusaha yang seluas-luasnya.

\section{Pembahasan}

\section{Konsep Dasar Pemasaran}

Secara umum, pemasaran dipandang sebagai tugas untuk menciptakan, memperkenalkan dan menyerahkan barang dan jasa kepada konsumen dan perusahaan lain. Menurut Kotler, definisi pemasaran dapat dilihat secara sosial dan secara manajerial. Secara social, Kotler mendefinisikan pemasaran sebagai proses social yang dengan proses itu individu dan kelompok mendapatkan apa yang mereka butuhkan dan inginkan dengan menciptakan, menawarkan dan secara bebas mempertukarkan produk dan jasa yang bernilai dengan produk lain. Sedangkan secara manajerial, pemasaran didefinisikan sebagai seni menjual produk. ${ }^{75}$

${ }^{75}$ Kotler, Philip. 2005. Manajemen Pemasaran. Edisi Bahasa Indonesia. Jilid 1. 
Menurut American Marketing Association dalam Tjiptono dan Anastasia Diana, pemasaran adalah aktivitas, serangkaian institusi, dan proses menciptakan, mengkomunikasikan, menyampaikan, dan mempertukarkan tawaran (offering) yang bernilai bagi pelanggan, klien, mitra dan masyarakat umum. Sedangkan menurut UK Charted Intitute of Marketing, pemasaran adalah proses manajemen yang mengidentifikasi, mengantisipasi, dan menyediakan apa yang dikehendaki pelanggan secara efesien dan menguntungkan. ${ }^{76}$

Berdasarkan dari beberapa definisi di atas terkait pemasaran, maka dapat disimpulkan bahwa pemasaran tidak hanya berhubungan dengan penjualan saja, tetapi lebih dari itu. Artinya bahwa penjualan hanya sebagian kecil dari pemasaran. Pemasaran merupakan sebuah kegiatan kompleks yang diawali dengan pencarian kebutuhan konsumen, penciptaan produk, mengkomunikasikan, menyampaikan dan menangkap kembali nilai dari pelanggan untuk memberikan kepuasan kepada konsumen dengan berbagai motif atau tujuan oleh pemasar.

Tjiptono menyebutkan ada sepuluh jenis bentuk/entitas produk, yaitu: 77

a) Barang (seperti : sepatu, komputer, dan pakaian)

b) Jasa (seperti : pendidikan, penerbangan, dan hotel)

c) Event (seperti : pameran, olimpiade, dan piala dunia)

d) Pengalaman (seperti : pendakian gunung)

e) Orang (seperti : calon legislatif, artis, dan atlet)

f) Tempat (seperti : kota, Negara, dan objek wisata spesifik)

g) Property (seperti : real estate, saham dan obligasi)

h) Organisasi (seperti : partai politik dan universitas)

${ }^{76}$ Tjiptono, Fandi dan Anastasia Diana. 2017. Pemasaran Esensi \& Aplikasi.

${ }_{77}$ Tjiptono, Fandi. 2016. Pemasaran Esensi \& Aplikasi. 
i) Informasi (seperti : buku, majalah, dan search engines)

j) Gagasan (seperti : konsep bisnis Total Quality Management)

\section{Lingkup Pemasaran}

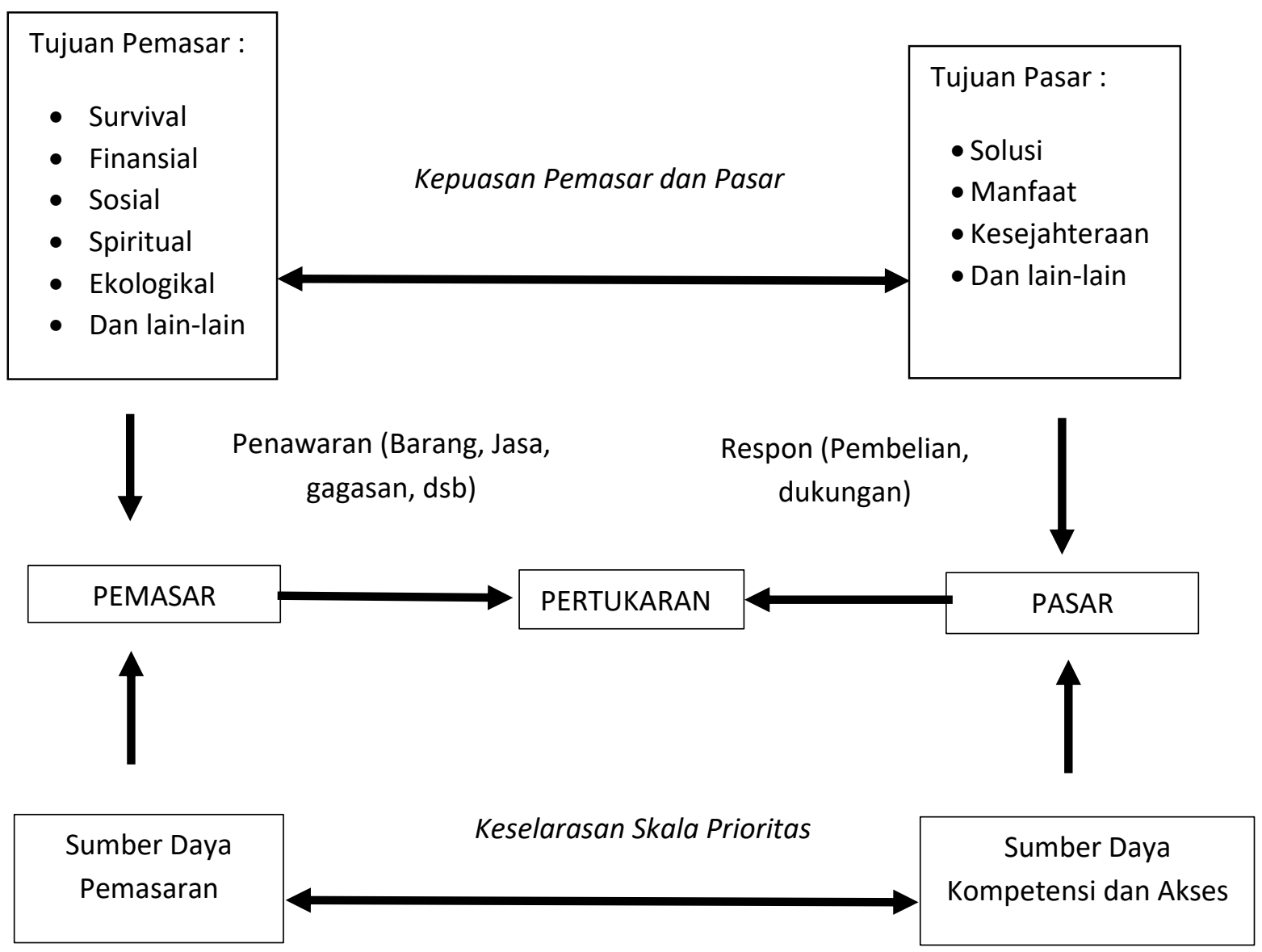

\section{Gambar 1 LINGKUP PEMASARAN78}

Ada beberapa elemen utama lingkup pemasaran seperti pada Gambar 1 yang dapat dijelaskan sebagai berikut:

1) Pemasar adalah individu maupun organisasi yang mencari respon (baik berupa perhatian, pembelian, donasi, maupun suara dukungan) dari pihak lain;

${ }^{78} \mathrm{Ibid}$. 
2) Setiap pemasar memiliki berbagai macam tujuan yang ingin diwujudkan, seperti survival (kelangsungan hidup), tujuan finansial (penjualan dan laba), tujuan strategik (pangsa pasar, pijakan bisnis, pengalaman bisnis, jejaring bisnis, dan seterusnya, tujuan social (kesejahteraan masyarakat, pelayanan publik, mengatasi isu-isu sosial kemasyarakatan, tujuan ekologi (kesadaran lingkungan, konservasi lingkungan), dan lain-lain.

\section{Strategi Promosi}

Promosi atau komunikasi pemasaran merupakan salah satu bagian dari bauran pemasaran (marketing mix). Menurut Hasan, promosi merupakan proses mengkomunikasikan variable bauran pemasaran (marketing mix) yang sangat penting untuk dilaksanakan oleh perusahaan dalam memasarkan produk. ${ }^{79}$ Sedangkan menurut Tjiptono, promosi berupa aktivitas komunikasi dengan pelanggan sasaran dalam rangka menginformasikan, mengingatkan kembali, dan/atau membujuk mereka untuk membeli produk. ${ }^{80}$ Promosi merupakan fungsi pemasaran yang focus untuk mengkomunikasikan program-program pemasaran secara persuasive kepada target pelanggan atau calon pelanggan untuk mendorong terciptanya transaksi pertukaran antara perusahaan dan pelanggan. Kegiatan promsi yang ideal adalah mengintegrasikan semua elemen promosi untuk menciptakan dialog interaktif (conversation) secara konsisten antara perusahaan dengan pelanggan. Jadi, bisa dikatakan bahwa promosi merupakan bentuk komunikasi pemasaran sebuah produk (baik barang, jasa, tempat, ataupun jenis produk yang lainnya) dengan pelanggan atau masyarakat.

\footnotetext{
${ }^{79}$ Hasan, Ali. 2013. Marketing dan Kasus-kasus Pilihan.

${ }^{80}$ Opcit. Tjiptono, Fandi. 2016. Pemasaran Esensi \& Aplikasi.
} 
Secara garis besar, komunikasi pemasaran memiliki tiga tujuan utama, yakni informing, persuading, dan reminding. Namun, seiring berkembangnya teknologi informasi dan komunikasi, komunikasi pemasaran yang efektif juga dituntut mampu memberikan aspek lainnya, yakni engaging, entertaining, empowering, dan educating. ${ }^{81}$

Instrumen Bauran Promosi (Promotion Mix)

Tabel 1 Deskripsi dan Contoh Alat Bauran Komunikasi

Pemasaran 82

\begin{tabular}{|c|c|c|}
\hline $\begin{array}{c}\text { Bentuk } \\
\text { Komunikasi } \\
\text { Pemasaran }\end{array}$ & Deskrispi & Contoh \\
\hline Periklanan & $\begin{array}{lr}\text { Segala } & \text { bentuk } \\
\text { presentasi } & \text { dan } \\
\text { promosi gagasan, } \\
\text { barang atau jasa yang } \\
\text { dibayar oleh sponsor } \\
\text { yang teridentifikasi. }\end{array}$ & $\begin{array}{l}\text { Iklan media cetak, } \\
\text { iklan media } \\
\text { elektronik, kemasan, } \\
\text { brosur, buklet, } \\
\text { leaflet, dan lain-lain }\end{array}$ \\
\hline $\begin{array}{l}\text { Promosi } \\
\text { Penjualan }\end{array}$ & $\begin{array}{lr}\text { Berbagai } & \text { macam } \\
\text { insentif jangka pendek } \\
\text { yang } & \text { dimaksudkan } \\
\text { untuk } & \text { mendorong } \\
\text { percobaan } & \text { atau } \\
\text { pembelian } & \text { produk } \\
\text { atau jasa. }\end{array}$ & 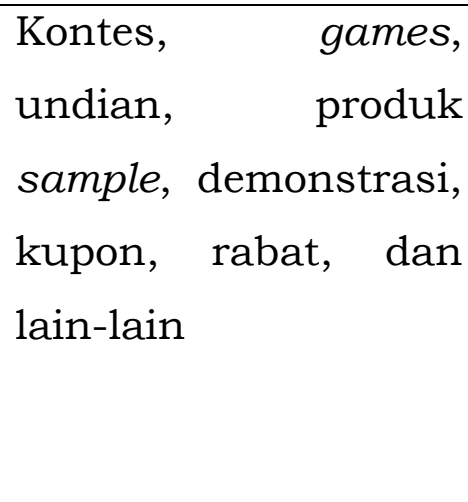 \\
\hline $\begin{array}{l}\text { Public } \\
\text { Relations }\end{array}$ & $\begin{array}{l}\text { Berbagai } \\
\text { program } \\
\text { dirancang }\end{array}$ & $\begin{array}{ll}\text { Pidato, } & \text { seminar, } \\
\text { laporan } & \text { tahunan, }\end{array}$ \\
\hline
\end{tabular}

${ }^{81} \mathrm{lbid}$.

${ }^{82} \mathrm{Ibid}$. 


\begin{tabular}{|c|c|c|}
\hline & $\begin{array}{ll}\text { mempromosikan } & \text { atau } \\
\text { melindungi } & \text { citra } \\
\text { perusahaan } & \text { atau } \\
\text { produk individualnya. }\end{array}$ & $\begin{array}{l}\text { donasi, sponsorship, } \\
\text { dan lain-lain }\end{array}$ \\
\hline $\begin{array}{c}\text { Personal } \\
\text { Selling }\end{array}$ & $\begin{array}{l}\text { Interaksi tatap muka } \\
\text { dengan satu atau } \\
\text { lebih calon pembeli } \\
\text { untuk melakukan } \\
\text { presentasi, menjawab } \\
\text { pertanyaan, dan } \\
\text { mendapatkan } \\
\text { pesanan. }\end{array}$ & $\begin{array}{l}\text { Presentasi penjualan, } \\
\text { pertemuan penjualan, } \\
\text { program insentif, } \\
\text { produk sampel, dan } \\
\text { pameran dagang }\end{array}$ \\
\hline $\begin{array}{l}\text { Direct } \quad \& \\
\text { Online } \\
\text { Marketing }\end{array}$ & $\begin{array}{l}\text { Penggunaan surat, } \\
\text { telepon, fax, email } \\
\text { atau internet untuk } \\
\text { berkomunikasi secara } \\
\text { langsung dengan } \\
\text { pelanggan atau untuk } \\
\text { mendapatkan respon } \\
\text { secara langsung dari } \\
\text { pelanggan dan calon } \\
\text { pelanggan spesifik. }\end{array}$ & $\begin{array}{l}\text { Katalog, surat, } \\
\text { telemarketing, } \\
\text { electronic shopping, } \\
\text { TV shopping, fax, } \\
\text { email, voice mail, dan } \\
\text { lain-lain }\end{array}$ \\
\hline
\end{tabular}

\section{Komunikasi Pemasaran Terpadu}

Menurut Adrienne dalam Morrissan, Komunikasi Pemasaran Terpadu (Integrated Marketing Communication/IMC), mencakup upaya 
koordinasi dari berbagai elemen promosi dan kegiatan pemasaran lainnya. ${ }^{83}$ Sedangkan menurut American Association of Advertising Agencies dalam Kotler dan Killers, Komunikasi Pemasaran Terpadu adalah konsep yang mengakui nilai tambah suatu rencana yang komprehensif. Rencana semacam itu mengevaluasi peran strategis berbagai disiplin komunikasi - misalnya iklan umum, tanggapan langsung, promosi penjualan, dan hubungan masyarakat - serta menggabungkan disiplin-disiplin ini untuk memberikan kejelasan, konsistensi dan pengaruh maksimum melalui intergrasi pesan-pesan yang saling berlainan secara mulus. ${ }^{84}$ Berdasarkan definisi tersebut, dapat ditarik kesimpulan bahwa Komunikasi Pemasaran Terpadu (Integrated Marketing Communication/IMC) merupakan upaya yang dilakukan terkait komunikasi produk perusahaan dengan menggunakan beberapa bentuk kegiatan komunikasi yang selama ini terpisah melalui koordinasi atau integrasi berbagai elemen promosi.

Tom Duncan dan Sandra Moriarty dalam Morissan (2015:10) menyatakan bahwa IMC merupakan pendekatan pemasaran "generasi baru" yang digunakan perusahaan untuk lebih memfokuskan upaya mereka dalam memperoleh, mempertahankan dan mengembangkan hubungan perusahaan dengan para pelanggan serta pihak-pihak terkait lainnya. Morissan mengungkapkan bahwa komunikasi pemasaran terpadu merupakan upaya untuk menjadikan seluruh kegiatan pemasaran dan promosi perusahaan dapat menghasilkan citra atau image yang bersifat satu dan konsisten bagi konsumen. Dilanjutkan oleh Morissan bahwa upaya ini menuntut agar setiap pesan yang keluar harus berasal dari sumber yang sama sehingga

\footnotetext{
${ }^{83}$ Morrissan. 2015. Periklanan Komunikasi Pemasaran Terpadu.

${ }^{84}$ Kotler, Philip dan Killers. 2007. Manajemen Pemasaran.
} 
segala informasi yang diumumkan perusahaan memiliki kesamaan tema serta positioning yang sama di mata konsumen. 85

Morissan mengatakan bahwa dalam merancang strategi promosi, perusahaan harus mengombinasikan berbagai elemen yang terdapat dalam bauran promosi atau promotional mix dengan memperhitungkan kekuatan dan kelemahan dari elemen-elemen tersebut. Manajemen promosi (promotional management) mencakup kegiatan mengkoordinasikan elemen-elemen bauran promosi sehingga dapat mengembangkan program komunikasi pemasaran yang terpadu, terkontrol dan efektif. ${ }^{86} \mathrm{Hal}$ ini berarti dalam melakukan strategi promosi ini perusahaan atau penyedia produk dapat menggunakan beberapa bauran promosinya untuk mencapai tujuan.

\section{Wisata, Pariwisata, dan Kepariwisataan}

Menurut Undang-undang Nomor 10 Tahun 2009 Pasal 1 Angka 1, 3 dan 4 tentang Kepariwisataan dalam Antariksa, dijelaskan definisi mengenai istilah Wisata, Pariwisata, dan Kepariwisataan sebagai berikut : 87

a) Wisata adalah kegiatan perjalanan yang dilakukan oleh seseorang atau sekelompok orang dengan mengunjungi tempat tertentu untuk tujuan rekreasi, pengembangan pribadi, atau mempelajari keunikan daya tarik wisata yang dikunjungi dalam jangka waktu sementara.

b) Pariwisata adalah berbagai macam kegiatan wisata dan didukung berbagai fasilitas serta layanan yang disediakan oleh masyarakat, pengusaha, Pemerintah, dan Pemerintah Daerah.

${ }^{85}$ Opcit. Morrissan. 2015. Periklanan Komunikasi Pemasaran Terpadu.

${ }^{86} \mathrm{lbid}$.

${ }^{87}$ Antariksa, Basuki. 2018. Kebijakan Pembangunan Sadar Wisata Menuju Daya Saing Kepariwisataan Berkelanjutan. 
c) Kepariwisataan adalah keseluruhan kegiatan yang terkait dengan pariwisata dan bersifat multidimensi serta multidisiplin yang muncul sebagai wujud kebutuhan setiap orang dan Negara serta interaksi antara wisatawan dan masyarakat setempat, sesame wisatwan, Pemerintah, Pemerintah Daerah dan pengusaha.

\section{Wisata Religi/Wisata Agama}

Menurut Yoeti dalam Sukayat, wisata agama atau wisata ziarah atau wisata pilgrim adalah jenis wisata yang dilakukan untuk melihat atau menyaksikan upacara-upacara keagamaan. ${ }^{88}$ Sedangkan Pendit dalam Sukayat mengatakan bahwa wisata pilgrim adalah jenis wisata yang sedikit banyak dikaitkan dengan agama, sejarah, adat istiadat, dan kepercayaan umat atau kelompok dalam masyarakat. Wisata pilgrim banyak dilakukan oleh perorangan atau rombongan ke tempattempat suci, ke makam-makam orang besar atau pemimpin yang diagungkan. ${ }^{89}$ Kemudian, Soekadijo dalam Sukayat menyatakan bahwa wisata spiritual merupakan salah satu tipe wisata yang tertua. ${ }^{90}$ Adapun maksud atau motivasi utama wisata keagamaan menurut Sammeng dalam Sukayat adalah melakukan perjalanan kunjungan ke suatu tempat untuk hal-hal yang berkaitan dengan keagamaan. ${ }^{91}$

Indonesia memiliki beragam wisata religi yang disebabkan oleh adanya beragam agama yang dianut oleh penduduknya. Adapun agama yang diakui secara resmi di Indonesia adalah Islam, Kristen Protestan, Katolik, Hindu, Budha, dan Kong Hu Cu. Perayaan tahun baru Agama Budha (Waisyak) di Candi Borobudur, Hari Panca Wali

\footnotetext{
${ }^{88}$ Sukayat, Tata. 2016. Manajemen Haji, Umrah, dan Wisata Agama.

$89 \mathrm{lbid}$.

${ }^{90} \mathrm{lbid}$.

${ }^{91}$ Ibid.
} 
Krama yang diselenggarakan setiap 10 tahun di Pura Besakih Bali bagi umat Hindu, dan Ziarah ke makam para wali bagi umat Islam, adalah beberapa contoh bentuk wisata religi di Indonesia yang mampu menarik minat para wisatawan.

Sebelum mengadakan perjalanan untuk rekreasi, bisnis, olahraga, dan sebagainya, orang sudah mengadakan perjalanan untuk melakukan ziarah. Berdasarkan Kamus Besar Bahasa Indonesia (KBBI), ziarah berarti kunjungan ke tempat yang dianggap keramat atau mulia seperti makam dan sebagainya. ${ }^{92}$ Secara etimologi, ziarah berasal dari bahasa Arab, yakni ziyarah yang artinya kunjungan, mengunjungi atau mendatangi. ${ }^{93}$ Ziarah sering diidentikkan dengan kubur, yakni lobang yang digali ditanah berukuran 1 x $2 \mathrm{~m}$ berbentuk persegi panjang disertai liang lahat yang merupakan tempat penimpanan mayat/jenazah manusia. ${ }^{94}$ Secara terminology, ziarah berarti mengunjungi sewaktu-waktu kuburan orang yang sudah meninggal dunia untuk memohonkan rahmat Tuhan bagi orang-orang yang dikubur di dalamnya serta untuk mengambil ibarat dan peringatan supaya hidup ingat akan mati dan nasib di kemudian hari di akhirat. 95

Ziarah dapat dilakukan kapan saja, tanpa ada batasan waktu. Tetapi pada umumnya ziarah sering dilakukan pada hari Jum'at, menjelang hari raya Idul Fitri, ataupun pada bulan-bulan tertentu saat perayaan hari besar. Ziarah kubur biasanya dilakukan dengan mengunjungi makam leluhur, keluarga, kerabat, tokoh masyarakat, ulama, wali, dan nabi yang dianggap telah berjasa dalam perkembangan agama Islam.

\footnotetext{
92 https://kbbi.web.id/ziarah

${ }_{93}$ Jamaluddin. 2014. Tradisi Ziarah Kubur Dalam Masyarakat Melayu Kuantan.

${ }_{94} \mathrm{Ibid}$.

${ }^{95}$ al-Farizi, Hariz. 2003. Rahasia Ziarah Kubur.
} 


\section{Keutamaan Ziarah Kubur}

Yulian Purnama mengemukakan mengenai keutamaan ziarah kubur:96

Rasulullah Shallallahu'alaihi Wasallam bersabda:

Dari Abu Bakr bin Abi Syaibah dan Zuhair bin Harb, mereka berdua berkata: Muhammad Bin 'Ubaid menuturkan kepada kami: Dari Yaziid bin Kasyaan, ia berkata: Dari Abu Haazim, ia berkata: Dari Abu Hurairah, ia berkata: Rasulullah Shallallahu'alaihi Wasallam berziarah kepada makam ibunya, lalu beliau menangis, kemudian menangis pula lah orang-orang di sekitar beliau. Beliau lalu bersabda: "Aku meminta izin kepada Rabb-ku untuk memintakan ampunan bagi ibuku, namun aku tidak diizinkan melakukannya. Maka aku pun meminta izin untuk menziarahi kuburnya, aku pun diizinkan. Berziarah-kuburlah, karena ia dapat mengingatkan engkau akan kematian"

(HR. Muslim no.108, 2/671)

\section{Sejarah Makam Surgi Mufti}

Makam Surgi Mufti atau ada juga yang menyebut Kubah Surgi Mufti merupakan makam seorang ulama yang bernama $H$. Jamaluddin. Beliau merupakan cicit Syekh Muhammad Arsyad AlBanjari atau Datuk Kalampayan dari garis istri beliau yang keenam, bernama Ratu Aminah binti Pangeran Thaha (seorang bangsawan Kerajaan Banjar). Silsilah Tuan Guru Surgi Mufti ini adalah Mufti

${ }^{96}$ https://muslim.or.id/8610-keutamaan-ziarah-kubur.html 
Jamaluddin bin Zalekha binti Pangeran Mufti H. Ahmad bin Syekh Muhammad Arsyad al-Banjari (datu kalampayan).

Syekh Jamaluddin Al-Banjari atau Tuan Guru Surgi Mufti dilahirkan di Desa Dalam Pagar, Astambul, Martapura, pada tahun 1817. Beliau adalah putra dari pasangan H. Abdul Hamid dan $\mathrm{Hj}$. Jaleha. Semasa hidupnya, Tuan Guru H. Surgi Mufti dikenal sebagai ulama besar yang terkenal pemurah, ramah, serta disegani oleh berbagai kalangan, termasuk Belanda. Banyak orang-orang yang belajar dan menuntut ilmu kepada beliau. Sejak remaja, dia sudah menimba ilmu di tanah suci Makkah Al-Mukarromah. Beliau termasuk jaringan Ulama Haramain (tanah haram). Sekitar tahun 1894, beliau kembali ke Banjarmasin di masa-masa konfrontasi dengan Belanda yang menjajah Indonesia.

Istilah surgi memiliki arti suci, sedangkan mufti artinya pemimpin. Gelar ini diberikan kepada Haji Jamaluddin oleh Belanda karena beliau dinilai istiqomah dalam memelihara kesucian hati dan tekun ibadah. Walaupun hidup dan tumbuh di zaman pemerintahan Belanda, namun keteguhan beliau dalam beribadah menunjukkan bahwa kekuatan ilmu agama lebih mulia daripada urusan dunia. Cara beliau berdakwah disukai dan dinantikan oleh para muridnya.

Banyak orang-orang yang belajar dan menuntut ilmu kepada beliau. Beliau diangkat menjadi mufti oleh pemerintah Belanda dan berkedudukan di Banjarmasin pada tahun 1896. Beliau wafat pada tanggal 8 Muharram 1348 H (1902) dan dimakamkan di depan rumah beliau di Jalan Masjid Jami Banjarmasin. Oleh Pemerintah, makam beliau kemudian ditetapkan sebagai salah satu peninggalan dan cagar budaya yang dilindungi hingga sekarang dikenal oleh masyarakat Banjar dengan nama Kubah Sungai Jingah. Gelar beliau juga 
diabadikan menjadi nama satu kelurahan dalam wilayah Kecamatan Banjarmasin Utara, yakni Kelurahan Surgi Mufti.

Makam ini berkelambu dan dilapisi kain kuning. Di samping kanan makam Syekh Jamaluddin Al-Banjari ada dua makam yang berukuran lebih kecil, yaitu makam dua anak Haji Jamaluddin (Syekh Surgi Mufti). Sementara di samping kirinya merupakan makam Hj. Siti Aisyah yang merupakan isteri dari Syekh Surgi Mufti. Makam ini berada di dalam bangunan berupa kubah, letaknya di halaman sebuah rumah tradisional Banjar. Rumah tersebut sekarang dijadikan museum berbagai peninggalan Syekh Surgi Mufti yang bisa dikunjungi peziarah. Di dindingnya ada beberapa dokumen dan foto penting tentang Syekh Surgi Mufti beserta keluarganya.

\section{Pembahasan Strategi Promosi Makam Syekh Surgi Mufti}

Berdasarkan pada jenis atau entitas produk, Makam atau Kubah Syekh Surgi Mufti tergolong entitas produk berupa tempat. Pengunjung atau peziarah yang datang ke sana bermaksud untuk mengunjungi tempat tersebut dengan berbagai tujuan. Menurut informasi yang didapat dari peziarah, kedatangan mereka didasari pada beberapa maksud atau motivasi, antara lain untuk mendoakan Syekh Surgi Mufti, sebagai bentuk pengingat akan kematian, serta ada pula yang datang untuk memenuhi hajat mereka.

Menurut informasi yang diperoleh dari pengelola kubah yang merupakan cucu dari Syekh Surgi Mufti mengatakan bahwa pintu Kubah Syekh Surgi Mufti tidak pernah ditutup. Hal ini dilakukan agar para peziarah dapat melakukan ziarah kapan saja sehingga tidak membatasi para peziarah jika ingin berkunjung. Disampaikan pula bahwa Makam Syekh Surgi Mufti tidak pernah sepi dari peziarah dan pengunjung. Jumlah peziarah yang lebih banyak biasanya di akhir 
pekan atau ketika hari libur. Bahkan ketika haul yang dilaksanakan pada 8 Muharram setiap tahunnya, peziarah yang datang sangat banyak dari berbagai daerah.

Makam Syekh Surgi Mufti menjadi salah satu objek wisata religi yang ditetapkan sebagai situs cagar budaya yang dilindungi oleh Undang-Undang Republik Indonesia Nomor 11 Tahun 2010. Selama ini, Makam Syekh Surgi Mufti dikelola oleh keturunan beliau. Menurut cucu beliau yang bernama Siti Armiziah Arsyad yang merupakan juru kunci makam, kubah ini sudah mengalami renovasi melalui bantuan pemerintah Provinsi Kalimantan Selatan. Hal ini dilakukan demi menjaga kondisi sekitar makam tetap terpelihara.

Mengingat keberadaan makam Syekh Surgi Mufti yang sudah ditetapkan sebagai situs cagar budaya, maka penting untuk terus diupayakan berbagai strategi agar tingkat kunjungan peziarah atau wisatawan semakin banyak. Melalui tingkat kunjungan yang semakin banyak diharapkan akan berdampak positif bagi Kalimantan Selatan maupun masyarakat sekitar, salah satunya yakni meningkatnya tingkat pendapatan. Salah satu strategi penting yang perlu dilakukan adalah melalui strategi promosi.

Berdasarkan pada informasi yang diperoleh dari Siti Armiziah Arsyad, cucu dari Syekh Surgi Mufti, memang belum ada upaya lebih yang dilakukan untuk menarik minat wisatawan atau peziarah. Selama ini peziarah yang datang bukan karena hasil dari promosi, tetapi karena memang mereka sudah mengetahui dan mengenal Syekh Surgi Mufti sebagai ulama besar. Hal yang sama juga disampaikan oleh bagian Destinasi dan bagian Pemasaran Dinas Pariwisata Provinsi Kalimantan Selatan, bahwa Makam Syekh Surgi Mufti masih dalam 
proses tahap pembentukan kawasan destinasi, sehingga belum diupayakan langkah promosi.

Meskipun dikatakan belum ada upaya lebih terkait strategi promosi yang dilakukan, namun sebagai langkah awal dalam rangka lebih mengenalkan Kubah Syekh Surgi Mufti sebagai situs cagar budaya, atas inisiatif masyarakat sekitar, di samping Makam Syekh Surgi Mufti sekarang dipasang papan reklame yang bertuliskan "Selamat Datang Di Wisata Religi Makam Datu Syurgi Mufti Bani Arsyadi Albanjari". Papan reklame ini dapat dikatakan salah satu upaya promosi yang menggunakan bauran promosi periklanan (advertising). Di dalam manajemen pemasaran, upaya promosi melalui advertising ini salah satunya bertujuan untuk memperkenalkan kepada khalayak ramai terkait sebuah produk.

Ada beberapa hal yang bisa dijadikan alasan mengapa strategi promosi menjadi penting dilakukan dalam pengelolaan Makam Syekh Surgi Mufti. Berdasarkan pada informasi yang didapatkan dari hasil observasi di lapangan dan wawancara dengan berbagai pihak, yakni pengelola makam, masyarakat sekitar dan instansi terkait, Makam Syekh Surgi Mufti yang saat ini merupakan situs cagar budaya memiliki faktor-faktor pendukung untuk terus dijaga, dikembangkan dan dilestarikan. Adapun factor-faktor pendukung yang menjadi kekuatan dari situs cagar budaya ini adalah sebagai berikut:

1. Image atau citra Syekh Surgi Mufti sebagai ulama besar

Melihat dari sejarah Syekh Surgi Mufti yang bernama asli Haji Jamaluddin sudah sangat dikenal luas oleh masyarakat Kalimantan

Selatan khususnya sebagai ulama besar dari keturunan Datu Kelampayan, Syekh Arsyad Al-Banjari, memberi peluang tersendiri dalam menarik minat peziarah untuk selalu datang. Pribadi beliau 
yang menurut cerita sejarah yakni ramah tamah, berpendirian kuat pada agama Islam dan dan disegani oleh berbagai kalangan, termasuk Belanda yang pada saat itu menjajah Indonesia, semakin menjadikan Syekh Surgi Mufti patut untuk dijadikan panutan oleh masyarakat. Selain itu, gelar surgi mufti yang berarti pemimpin yang suci diberikan Belanda kepada Haji Jamaluddin mengesankan bahwa beliau adalah sosok yang sangat berpengaruh dan disegani pada zaman penjajahan itu dan Belanda sebagai penjajahpun mengakuinya.

2. Lokasi yang strategis

Makam Syekh Surgi Mufti berlokasi di Jalan Jalan Mesjid Jami, Kelurahan Surgi Mufti, Kecamatan Banjarmasin Utara, Kota Banjarmasin berdekatan dengan Kelurahan Sungai Jingah. Pada awalnya secara administratif Kelurahan Surgi Mufti merupakan bagian dari Kelurahan Sungai jingah sehingga banyak masyarakat yang mengetahui bahwa Makam Syekh Surgi Mufti berada di Kampung Sungai Jingah. Kampung Sungai Jingah dikenal sebagai kampung tua yang identik dengan budaya sungai dengan jumlah peninggalan cagar budaya seperti rumah adat banjar yang cukup banyak. Selain itu, pemerintah Kota Banjarmasin telah menjadikan kampung Sungai Jingah sebagai Kawasan Kampung Banjar. Makam Syekh Surgi Mufti yang berada dekat dengan pinggiran sungai besar. Hal ini menjadikan makam Syekh Surgi Mufti ini menjadi lebih menarik dari sudut pandang wisata. Para peziarah atau pengunjung bisa menuju ke makam dengan menggunakan transportasi darat atau melalui alternative wisata sungai dengan menggunakan alat transportasi air seperti kelotok.

3. Dukungan yang kuat dari berbagai pihak 
Makam Syekh Surgi Mufti yang saat ini menjadi situs cagar budaya merupakan hasil kolaborasi yang baik dari berbagai pihak, yakni para keturunan dari Syekh Surgi Mufti sebagai pengelola makam, masyarakat sekitar dan pemerintah. Status Makam Syekh Surgi Mufti sebagai situs cagar budaya dilindungi oleh Undang-Undang Republik Indonesia Nomor 11 Tahun 2010. Berdasarkan undangundang ini, maka setiap orang dilarang merusak makam baik seluruh maupun sebagian-bagiannya. Berdasarkan undang-undang ini, bagi yang melakukan tindakan pelanggaran akan dikenakan denda berupa kurungan dan/atau denda. Hal ini merupakan salah satu bentuk dukungan pemerintah Provinsi Kalimantan Selatan guna melindungi dan melestarikan Makam Syekh Surgi Mufti. Makam Syekh Surgi Mufti dikelola dan dijaga oleh keturunan Syekh Surgi Mufti. Sebagai bentuk pelestarian tehadap peninggalan Syekh Surgi Mufti, rumah dengan arsitektur suku Banjar yang dahulunya merupakan tempat tinggal Syekh Surgi Mufti sekarang dijadikan museum. Di dalam rumah tersebut diletakkan berbagai barang ataupun hasil karya dari Syekh Surgi Mufti.

Berdasarkan hasil wawancara, salah satu upaya yang akan dilakukan untuk menarik minat masyarakat mengunjungi Makam Syekh Surgi Mufti adalah melalui upaya pembangunan Musholla Terapung Bani Arsyadi yang letaknya tepat berada diseberang Makam Syekh Surgi Mufti. Pembangunan musholla ini berdasarkan inisiatif warga masyarakat sekitar dengan sumber dana berupa hibah dan sumbangan dari berbagai pihak. Instansi terkait, yakni Dinas Pariwisata Provinsi Kalimantan Selatan ikut terlibat dalam upaya ini dengan rencana berupa pembuatan pintu gerbang. Di harapkan ke depannya, dengan keberadaan musholla apung ini akan menjadi daya 
tarik tersendiri sebagai salah satu destinasi tujuan wisata religi yang ada di Provinsi Kalimantan Selatan.

Salah satu upaya yang dapat ditawarkan dalam pengelolaan Makam Syekh Surgi Mufti melalui strategi promosi adalah dengan menggunakan konsep Komunikasi Pemasaran Terpadu (Integrated Marketing Communication/IMC). Komunikasi Pemasaran Terpadu (IMC) menawarkan sebuah konsep upaya untuk menjadikan seluruh kegiatan pemasaran dan promosi perusahaan dapat menghasilkan citra atau image yang bersifat satu dan konsisten bagi konsumen. Seperti apa yang disebutkan oleh Morissan bahwa upaya ini menuntut agar setiap pesan yang keluar harus berasal dari sumber yang sama sehingga segala informasi yang diumumkan perusahaan memiliki kesamaan tema serta positioning yang sama di mata konsumen. ${ }^{97}$

Dinas Pariwisata Provinsi Kalimantan Selatan yang merupakan pihak yang turut berwenang dalam pengelolaan Makam Syekh Surgi Mufti bisa menggunakan elemen-elemen bauran promosi sebagai langkah strategi untuk lebih memperkenalkan Makam Syekh Surgi Mufti sebagai sebuah wisata religi. Adapun bauran promosi yang bisa diterapkan dalam strategi pengelolaan Makam Syekh Surgi Mufti salah satunya melalui periklanan (advertising). Periklanan merupakan bauran promosi yang melibatkan media massa (seperti televisi, radio, surat kabar, baliho, papan reklamen, dan sebagainya) dan bersifat non-personal (khalayak ramai). Adapun salah fungsi utama dari iklan ini adalah menginformasikan (information) kepada masyarakat luas tentang sebuah produk.

\footnotetext{
${ }^{97}$ Opcit. Morrissan. 2015. Periklanan Komunikasi Pemasaran Terpadu.
} 
Tidak bisa dipungkiri bahwa kemajuan teknologi sekarang ini sudah membawa berbagai dampak diberbagai bidang, salah satunya periklanan. Media periklanan saat ini semakin banyak menawarkan kreatif produk. Hal ini tentu saja akan berdampak pada hasil sampaian iklan tersebut sehingga dapat dikemas dengan sesuatu yang lebih menarik. Adapun contoh dari jenis iklan yang bisa digunakan untuk mempromosikan Makam Syekh Surgi Mufti antara lain melalui media televisi, surat kabar, radio, majalah, brosur, baliho, dan sebagainya.Tawaran dari iklan ini bisa dimanfaatkan secara optimal oleh Dinas Pariwisata Provinsi Kalimantan Selatan untuk memperkenalkan Makam Syekh Surgi Mufti sebagai salah satu produk unggulan wisata religi yang ditawarkan oleh Kalimantan Selatan. Meskipun demikian, perlu dipikirkan secara tepat pemilihan media iklan tersebut agar sesuai dengan jenis produk yang ditawarkan. Hal ini disebabkan berbagai jenis media iklan memiliki kelebihan dan kekurangan masing-masing.

Perkembangan komunikasi sekarang ini menyebabkan semakin banyaknya tawaran berbagai aplikasi seperti beberapa jenis media social (seperti facebook, twitter dan instagram). Dinas Pariwisata dapat membuat akun khusus untuk menginformasikan segala hal mulai dari sejarah sampai dengan kegiatan yang dilakukan di Makam Syekh Surgi Mufti. Hal ini memungkinkan lebih dekatnya informasi dengan masyarakat karena masyarakat sebagian besar familiar dengan aplikasi media social ini.

Bauran promosi lain yang bisa dilakukan untuk memperkenalkan Makam Syekh Surgi Mufti sebagai wisata religi adalah melalui hubungan masyarakat (public relation). Di dalam manajemen pemasaran, hubungan masyarakat ini dilakukan untuk 
menstimulasi permintaan sebuah produk atau jasa dengan cara menyampaikan berita yang siginifikan dan bersifat komersial, merancang berbagai program untuk mempromosikan dan atau melindungi citra perusahaan atau setiap produknya.98 Bentuk hubungan masyarakat yang dapat dilakukan antara lain dengan menyampaikan hal-hal terkait kegiatan-kegiatan di Makam Syekh Surgi Mufti seperti haul. Dinas Pariwisata Provinsi Kalimantan Selatan juga bisa menyampaikan tentang informasi apapun dari situs wisata religi Makam Syekh Surgi Mufti melalui website yang dimiliki, melalui media televisi, surat kabar, dan sebagainya. Misalnya informasi mengenai hal-hal menarik yang membuat situs wisata religi Makam Syekh Surgi Mufti wajib untuk dikunjungi. Selain itu, untuk meningkatkan kunjungan melalui bauran hubungan masyarakat ini, instansi terkait juga bisa mengadakan berbagai event yang bernilai religi disekitar kawasan Makam Syekh Surgi Mufti.

Selain beberapa hal di atas, untuk lebih memperkenalkan Makam Syekh Surgi Mufti sebagai wisata religi bisa pula dilakukan melalui personal selling. Penjualan personal (personal selling) merupakan bentuk presentasi secara lisan dengan satu atau lebih calon pembeli dengan tujuan penjualan. ${ }^{99}$ Personal selling merupakan bentuk bauran promosi yang lebih bersifat fleksibel karena dapat menyesuaikan bentuk komunikasi dengan lawan komunikasinya. Hal ini disebabkan karena personal selling dilakukan secara langsung oleh individu yang bisa dikatakan sebagai tenaga penjualnya sehingga dapat dengan mudah menyesuaikan cara penyampaian mengenai produk.

\footnotetext{
${ }^{98}$ Opcit. Hasan, Ali. 2013. Marketing dan Kasus-kasus Pilihan. ${ }^{99}$ Ibid.
} 
Dinas Pariwisata Kalimantan Selatan dapat melakukan bauran promosi personal selling melalui duta wisata. Duta wisata merupakan merupakan figure pariwisata yang merupakan perpanjangan tangan pemerintah yang tugasnya memperkenalkan dan mempromosikan potensi budaya dan pariwisata tertentu. Tujuannya adalah untuk menjaring lebih banyak para wisatawan local maupun asing untuk datang ke wilayah tertentu. 100 Berdasarkan pada definisi dan tujuan duta wisata ini, maka duta wisata dapat mempromosikan kepada siapapun, terlebih kepada para wisatawan tentang Makam Syekh Surgi Mufti sebagai wisata religi yang ditawarkan Kalimantan Selatan.

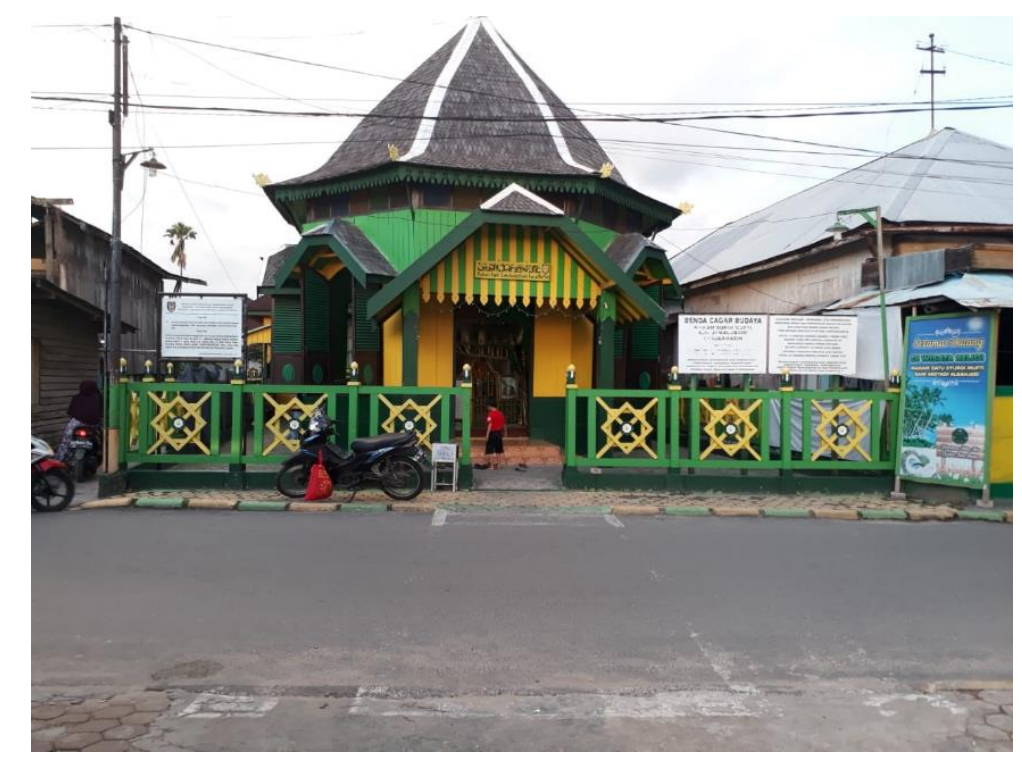

Gambar 2 Kubah Syekh Surgi Mufti di kawasan Jalan Mesjid Jami, Kelurahan Surgi Mufti, Kecamatan Banjarmasin Utara, Kota Banjarmasin

\footnotetext{
${ }^{100}$ www.pengertianmenurutparaahli.net/pengertian-duta-dan-konsul/
} 


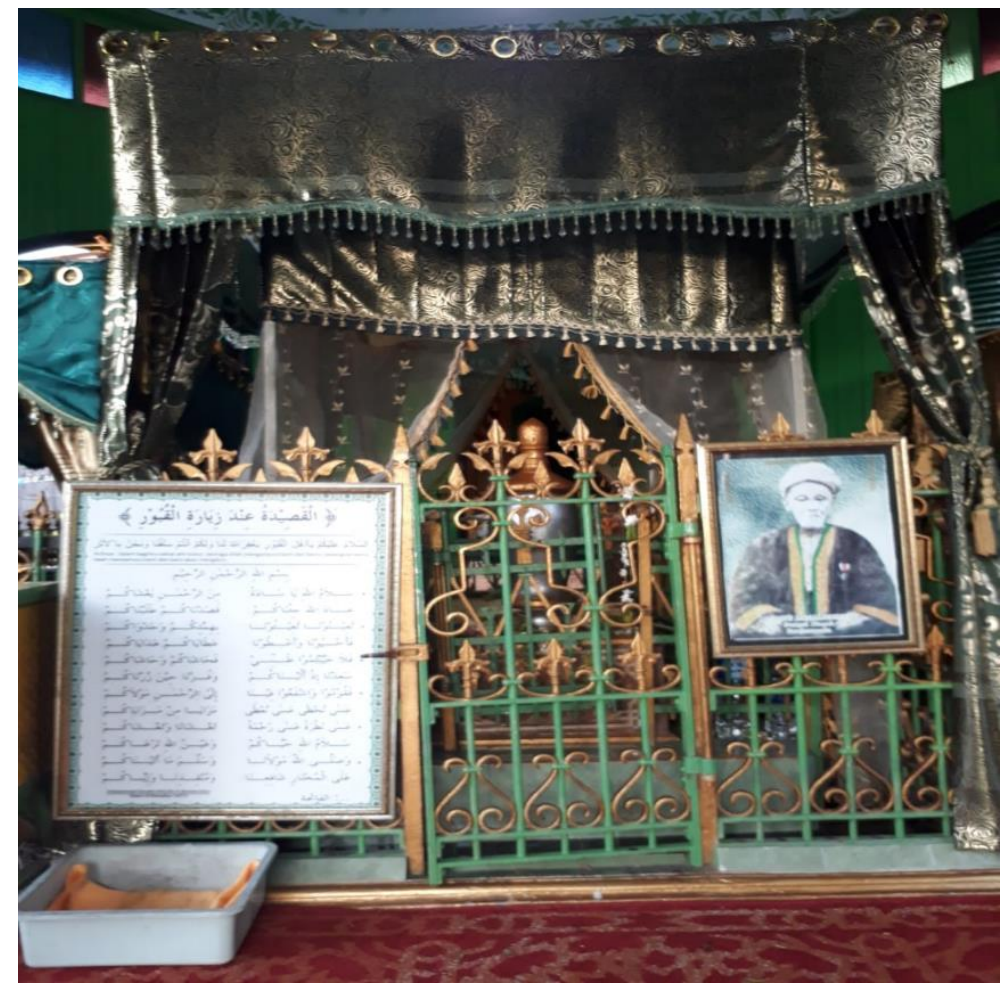

Gambar 3 Makam Syekh Surgi Mufti

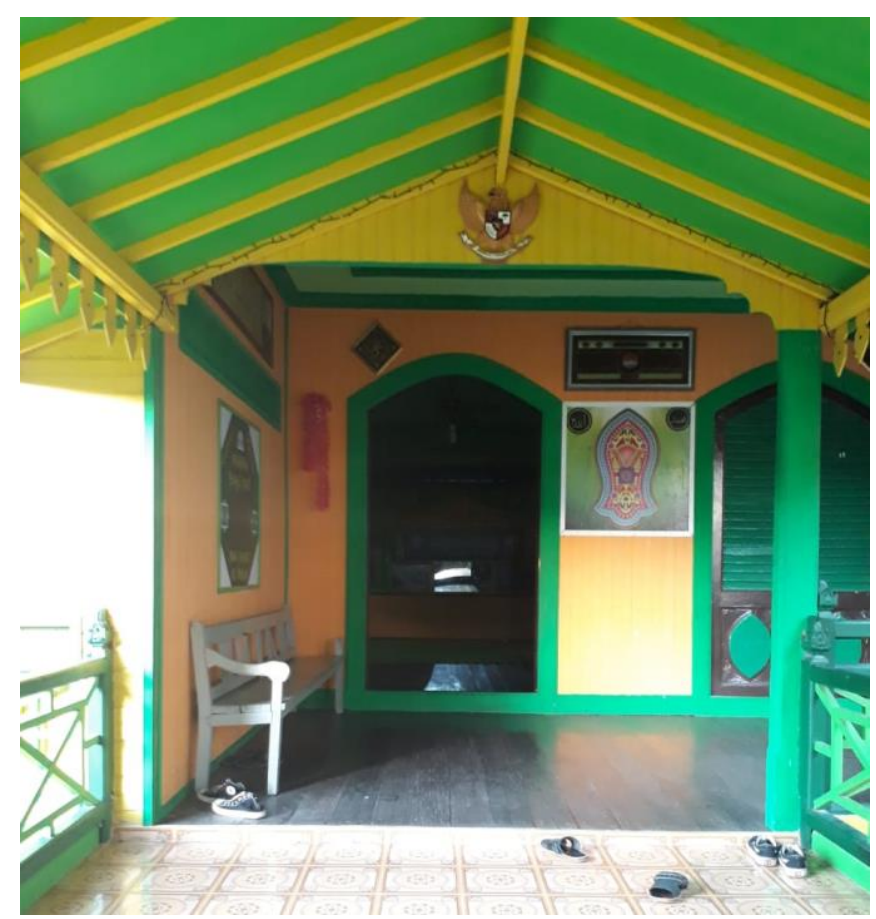

Gambar 4 Rumah Syekh Surgi Mufti yang berada di belakang makam 


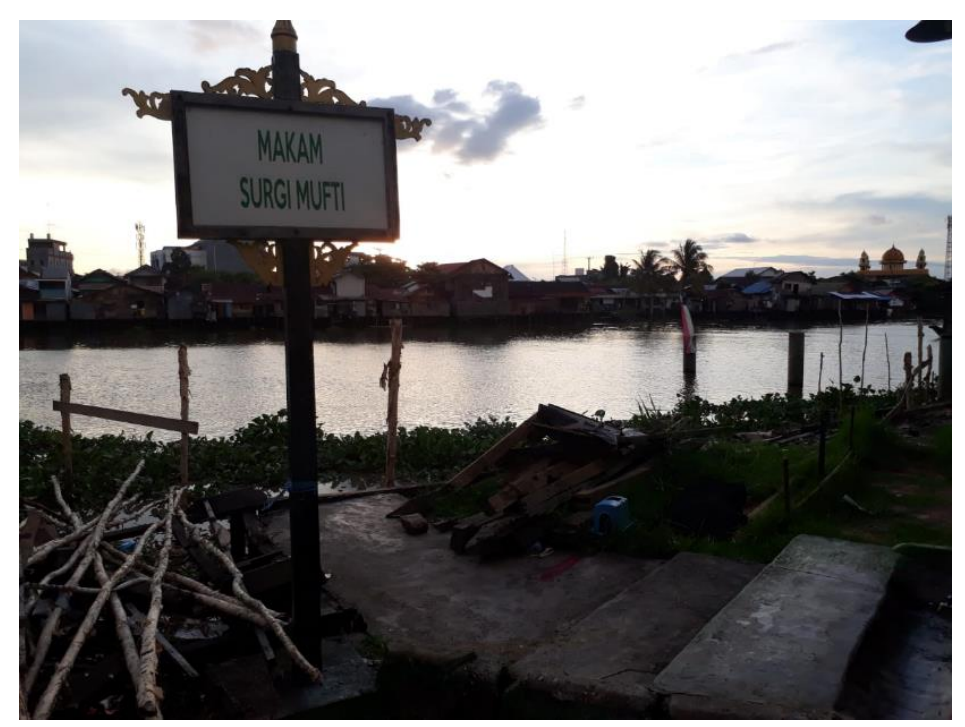

Gambar 5 Petunjuk sebagai tanda/identitas makam yang berada dekat dengan sungai. Di atas sungai tersebut sudah berdiri tiang untuk membangun Musholla Terapung

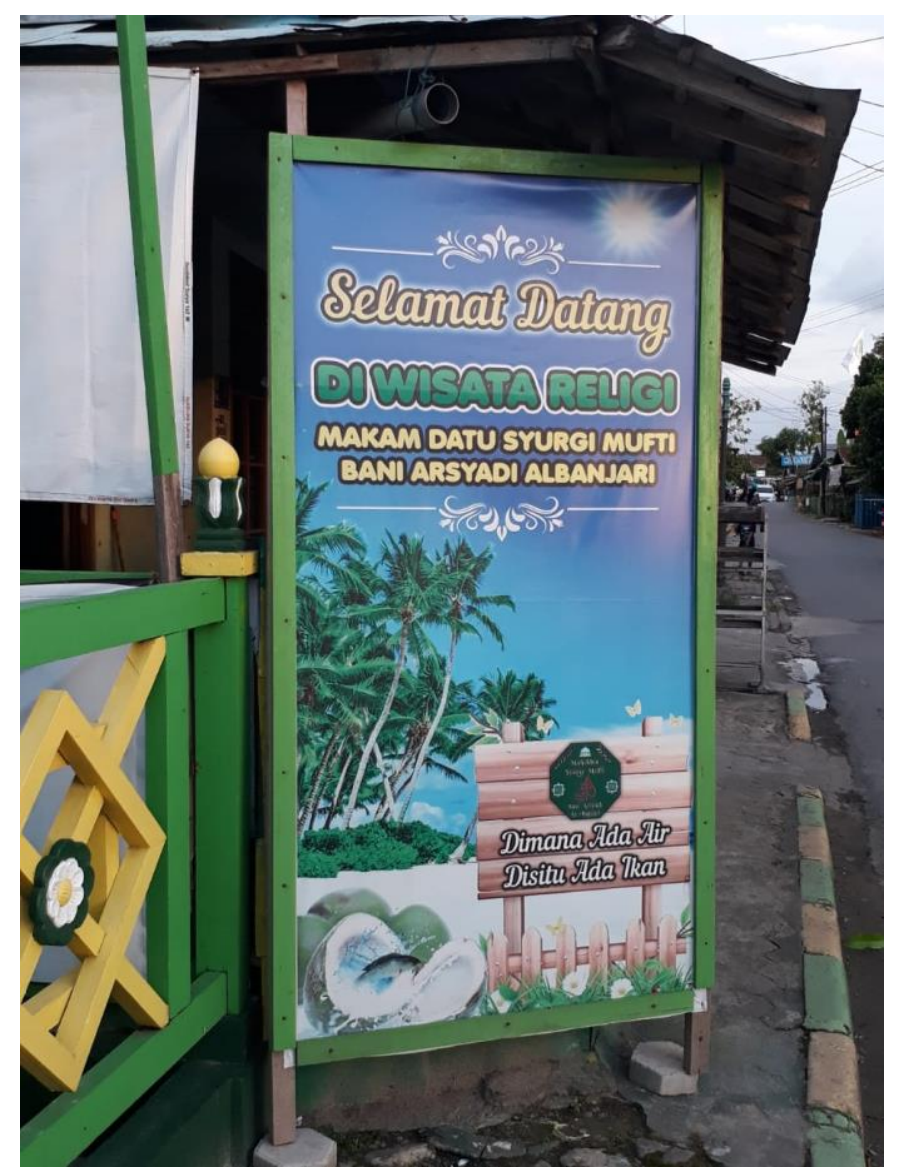

Gambar 6 Media papan reklame bertuliskan ucapan selamat datang 


\section{Daftar Pustaka}

al-Farizi, Hariz. 2003. Rahasia Ziarah Kubur. Jakarta: al-Sofwa Subur. Antariksa, Basuki. 2018. Kebijakan Pembangunan Sadar Wisata Menuju Daya Saing Kepariwisataan Berkelanjutan. Malang: Intrans Publishing.

Bungin, Burhan. 2015. Komunikasi Pariwisata (Tourism Communication) : Pemasaran dan Brand Destinasi. Jakarta : Kencana (Prenadamedia Group).

Hasan, Ali. Marketing dan Kasus-kasus Pilihan. 2013. Yogyakarta : CAPS.

Jamaluddin. 2014. Tradisi Ziarah Kubur Dalam Masyarakat Melayu Kuantan. UIN Sultan Syarif Kasim Riau.

Kotler, Philip. 2005. Manajemen Pemasaran. Edisi Bahasa Indonesia. Jilid 1. Jakarta: Indeks Gramedia.

Kotler, Philip dan Killers. 2007. Manajemen Pemasaran. Jakarta : Indeks.

Morrissan. 2010. Periklanan Komunikasi Pemasaran Terpadu. Jakarta : Kencana.

Sukayat, Tata. 2016. Manajemen Haji, Umrah, dan Wisata Agama. Bandung : Simbiosa Rekatama Media.

Tjiptono, Fandi. 2016. Pemasaran Esensi \& Aplikasi. Yogyakarta : Andi. https://hotel-management.binus.ac.id/2015/11/18/perkembanganpariwisata-indonesial https://kbbi.web.id/ziarah https://muslim.or.id/8610-keutamaan-ziarah-kubur.html 